\title{
THERMAL RECRYSTALLIZATION OF ALPHA-RECOIL DAMAGED MINERALS OF THE PYROCHLORE STRUCTURE TYPE
}

\begin{abstract}
By
G. R. Lumpkin*, E. M. Foltyn** and R. C. Ewing*

*Department of Geology, University of New Mexico, Albuquerque, New

Mexico, 87131 USA

**Los Alamos National Laboratory, Los Alamos, New Mexico, 87545 USA

\section{DISCLAIMER}

This report was prepared as an account of work sponsored by an agency of the United States Government. Neither the United States Government nor any agency thereof, nor any of their employees, makes any warranty, express or implied, or assumes any legal liability or responsibility for the accuracy, completeness, or usefulness of any information, apparatus, product, or process disclosed, or represents that its use would not infringe privately owned rights. Reference herein to any specific commercial product, process, or service by trade name, trademark, manufacturer, or otherwise does not necessarily constitute or imply its endorsement, recommendation, or favoring by the United States Government or any agency thereof. The views and opinions of authors expressed herein do not necessarily state or reflect those of the United States Government or any agency thereof.
\end{abstract}

This work performed under the auspices of the U.S. Department of Energy. 


\section{DISCLAIMER}

Portions of this document may be illegible in electronic image products. Images are produced from the best available original document. 


\section{ABSTRACT}

Thermal recrystallization effects (heat of recrystallization and identification of phases formed), have been determined for naturally occurring members of the pyrochlore group which have received alpha doses of up to $4 \times 10^{16}$ alphas/mg. The heats of recrystallization, $E_{t}$, range from 125 to $210 \mathrm{~J} / \mathrm{g}$. Release of energy decreases as a function of crystallinity (estimated on the basis of the intensity of $x$-ray diffraction maxima), with the fully-metamict samples approaching $210 \mathrm{~J} / \mathrm{g}$. Lower measured values $(40-125 \mathrm{~J} / \mathrm{g})$ are the result of alteration of the pyrochlores. Other metamict, complex oxides with stoichiometries of $\mathrm{ABO}_{4}$ and $\mathrm{AB}_{2} \mathrm{O}_{6}$ have lower heats of recrystallization $(40-85 \mathrm{~J} / \mathrm{g}$ ), and are easily distinguished from pyrochlore group minerals. Activation energies of recrystallization, $E_{\alpha}$, range between values of 0.29 to $0.97 \mathrm{eV}$, less than those measured for Pu-doped, synthetic zirconolites.

\section{INTRODUCTION}

Important among the potential host phases for actinides in polycrystalline nuclear waste forms are pyrochlore structure types [1-3] and the structural derivatives, e.g. zirconolite in SYNROC [4-7]. The long-term response of these crystalline phases to alpha and alpha-recoil damage (i.e. degradation of mechanical properties, increased leach rates and stored energy) are among the principal criteria in the evaluation of waste forms. Radiation effects have been studied in accelerated experiments in which synthetic pyrochlore and zirconolite have been doped 
with short-lived radionuclides $\left({ }^{238} \mathrm{Pu}\right.$ and $\left.{ }^{244} \mathrm{Cm}\right)$ and have experienced alpha-event doses of up to $10^{16}$ alphas $/ \mathrm{mg}\left(=10^{26}\right.$ alphas $\left./ \mathrm{m}^{3}\right)[8-11]$. We present the results of a study of the recrystallization of alpha-recoil damaged minerals of the pyrochlore group which have experienced doses of up to $4 \times 10^{16}$ alphas $/ \mathrm{mg} \quad\left(=10^{26}\right.$ alphas $\left./ \mathrm{m}^{3}\right)$ due to the decay of constituent ${ }^{238} \mathrm{U},{ }^{235} \mathrm{U},{ }^{232} \mathrm{Th}$ and radionuclides in their decay series. We should emphasize that in the case of fully-damaged, aperiodic ("metamict") materials, the energy released on heating is due to recrystallization, and not due to the thermal annealing of isolated defects or defect aggregates in an otherwise periodic structure. Comparison of these natural analogues to synthetic waste form phases can be used to evaluate dose rate effects (which vary by as much seven orders of magnitude) and to confirm the long-term extrapolation of the behaviour of the synthetic phases.

Pyrochlore group minerals have the general formula $A_{2-m} B_{2} X_{6} Y_{1-n} \dot{p} H_{2} O$, where $m=0.0-1.7, n=0.0-1.0$, and $p=0.0-2.5$. The A-site contains $\mathrm{Ca}, \mathrm{Na}$, $\mathrm{U}, \mathrm{Th}$, and rare earth elements as major cations and minor $\mathrm{Y}, \mathrm{Ba}, \mathrm{Sr}, \mathrm{Pb}, \mathrm{Bi}$, $\mathrm{Sb}, \mathrm{Mn}$, and $\mathrm{Fe}^{2+}$. The major $\mathrm{B}$-site cations include $\mathrm{Nb}, \mathrm{Ta}$, and $\mathrm{Ti}$ which are used to define the mineralogical subgroups: pyrochlore, $\mathrm{Nb}$-rich; microlite, Ta-rich; betafite, Ti-rich [12]. Minor B-site cations include Zr, $\mathrm{Sn}$, and $\mathrm{Fe}^{3+}$. This study presents data for members of all three mineralogical subgroups. The principal anions are $X=0 x y g e n$ and $Y=0, O H$, F. Minerals of the pyrochlore group occur as primary phases in carbonatites and granitic pegmatites. They are often subjected to hydrothermal (ca. $250-500^{\circ} \mathrm{C}$ ) or weathering (surface temperatures) alteration. The timing of alteration relative to radiation effects is based 
on textural observations [13]. Annealing studies require careful selection of well-characterized material with minimum evidence for alteration.

\section{EXPERIMENTAL TECHNIQUES}

\subsection{Differential Thermal Analysis (DTA)}

A Perkin-Elmer DTA- 1700 was used to analyze samples weighing from 60 to $140 \mathrm{mg}$. Samples were heated to $1200^{\circ} \mathrm{C}$ at a rate of $10^{\circ} \mathrm{C}$ per minute. All runs were completed in an atmosphere of argon flowing at a rate of $40 \mathrm{ml}$ per minute. The instrument was operated in the differential scanning calorimetry (DSC) mode and calibrated with pure metal standards. In order to evaluate stored energy and activation energy, the exothermic peak areas for three samples $(* 153, * 168$ and $* 204)$ were integrated using a planimeter at intervals ranging from $15^{\circ}$ to $80^{\circ} \mathrm{C}$.

\subsection{Thermogravimetric Analysis (TGA)}

A Dupont 951 TGA and 990 recorder were used to monitor weight change as a function of temperature. Samples weighing from 10 to $20 \mathrm{mg}$ were heated in air to $1000^{\circ} \mathrm{C}$ at a rate of $10^{\circ} \mathrm{C}$ per minute. The instrument was calibrated using calcium oxalate. The calibration was checked by reweighing each sample after cooling to room temperature and calculating the percentage of weight loss. The calculated and measured values of weight loss agreed to within \pm 5 percent. 
2.3. Electron Microprobe Analysis (EMPA)

Chemical analyses were obtained using an automated JEOL 733 electron microprobe operated at an accelerating voltage of $15 \mathrm{keV}$ and a sample current of $20 \mathrm{nA}$. Standards included natural samples of microlite (F, $\mathrm{Na}$, $\mathrm{Ca}, \mathrm{Nb}, \mathrm{Ta}$ ), manganotantalite $(\mathrm{Mn})$, stibiotantalite (Sb, $\mathrm{Bi}$ ), benitoite ( $\mathrm{Ti}$, $\mathrm{Ba})$, olivine ( $\mathrm{Fe})$, cerussite $(\mathrm{Pb})$, pollucite ( $\mathrm{Cs}$ ) and cassiterite ( $\mathrm{Sn}$ ). Synthetic crystals of $\mathrm{SrMOO}_{4}, \mathrm{ZrSiO}_{4}, \mathrm{CaWO}_{4}, \mathrm{YPO}_{4}, \mathrm{REEPO}_{4}, \mathrm{ThSiO}_{4}$, and $\mathrm{UO}_{2}$ were used for Sr, Zr, W, Y, REE, Th and U. Each element was counted until a standard deviation of 1.0 percent was reached, up to a maximum counting time of 30 seconds. To minimize volatilization induced by electron beam heating, all analyses were performed with a beam diameter of $10 \mathrm{um}$. The data were corrected for drift, deadtime, absorption, fluorescence and atomic number effects using a theoretical (ZAF) procedure based on the program MAGIC IV [14].

\subsection{X-Ray Diffraction (XRD)}

Samples were scanned from $20^{\circ}$ to $80^{\circ}$ two-theta at a rate of $2^{\circ}$ two-theta per minute using an Scintag automated diffractometer and

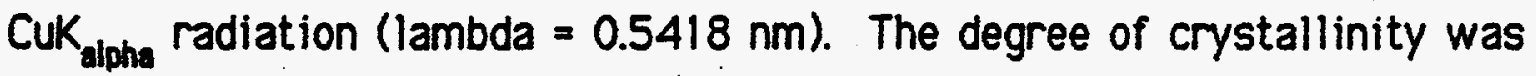
judged by reference to highly crystalline pyrochlore reference samples. Samples were run again following TGADTA runs in order to identify recrystallization products. Lattice constants were refined using the least squares program CELLREF [15]. 


\section{SAMPLE DESCRIPTION}

Most of the specimens examined are metamict. Their $x$-ray diffraction patterns display two diffuse bands corresponding to "equivalent" $d$-spacings of 0.30 and $0.18 \mathrm{~nm}$ [21]. Pyrochlore *230 was found to be moderately crystalline with $a_{0}=1.0419(1) \mathrm{nm}$ (standard deviation in parentheses refers to the last decimal place). Microlites $* 147$ and $* 201$ are highly crystalline with cell edges of $1.0429(1)$ and $1.0428(1) \mathrm{nm}$, respectively. Betafite $=155$ is the most severely altered sample. Virtually no $\mathrm{Ca}, \mathrm{Na}$ or $\mathrm{F}$ are present. Areas of relict betafite are surrounded by patches and spherulites of a Ti-rich phase and a U-rich phase. Both phases also occur in veinlets which crosscut the sample [13]. Sample $* 186$ has broken down into a fine-grained assemblage of betafite plus a $\mathrm{Nb}-\mathrm{Ti}$-Fe rich oxide (rutile-like phase), probably as a result of alteration. Alteration in microlite $* 080$ is confined to microfractures where leaching of $\mathrm{Ca}, \mathrm{Na}$, and $\mathrm{F}$ took place. Microscopic observations indicate that pyrochlores *214 and *251 also show significant alteration effects, mainly along narrow fractures. Samples $* 153, * 168$, and $* 204$ were selected for stored energy and activation energy measurements. They are described in further detail below and electron microprobe analyses are given in Table 1.

Microlite $* 153$ is from the microcline-spodumene zone of the Harding pegmatite, Taos Co., New Mexico [16]. The average composition given in Table 1 is close to that for unaltered material. Both primary (hydrothermal) and secondary (weathering) types of alteration are present $[13,16]$. Marginal primary alteration is characterized by increased $\mathrm{Ca}, \mathrm{Mn}$, 
and $\mathrm{Fe}$ and decreased $\mathrm{Na}$ at the A-site. Rare secondary alteration is confined to microfractures. Leaching of $\mathrm{Ca}, \mathrm{Na}$, and $\mathrm{F}$ and extensive hydration (up to $\sim 12$ wt. $\% \mathrm{H}_{2} \mathrm{O}$ ) are characteristic of these areas. X-ray diffraction work and transmission electron microscopy show that the sample is metamict [16].

Microlite 168 is from the blocky-albite unit of the Rutherford pegmatite, Amelia Co., Virginia. This specimen appears to be relatively unaltered, although secondary alteration has been reported in another sample $(* 080)$ from this locality [13]. The $x$-ray diffraction pattern shows weak (222), (440) and (622) reflections indicative of slight crystallinity.

Betafite *204 is from the Silver Crater mine near Bancroft, Ontario, Canada. The specimen is metamict, consisting of relatively unaltered betafite $\left(3-4\right.$ wt. $\left.\% \mathrm{H}_{2} \mathrm{O}\right)$ with increased hydration along fractures and voids (10-12 wt. \% $\left.\mathrm{H}_{2} \mathrm{O}\right)$. The average composition and alteration effects are similar to sample $* 083$ from the same locality $[13,17]$.

\section{EXPERIMENTAL RESULTS}

Results of DTA and TGA on the pyrochlore group minerals are given in Table 2. One sample of $\mathrm{ABO}_{4}$ and five samples of $\mathrm{AB}_{2} \mathrm{O}_{6}$ type, metamict, complex, $\mathrm{Nb}-\mathrm{Ta}-\mathrm{Ti}$ oxides are included for comparison. The metamict betafites and pyrochlores show exotherms ranging from $650^{\circ}$ to $700^{\circ} \mathrm{C}$, often accompanied by a smaller exotherm near $425^{\circ} \mathrm{C}$. An exception is pyrochlore $* 214$, which shows a strong exotherm at $410^{\circ} \mathrm{C}$ and a weaker peak at $620^{\circ} \mathrm{C}$. Moderately crystalline pyrochlore $\approx 230$ has weak 
exotherms at $430^{\circ}$ and $570^{\circ} \mathrm{C}$. Metamict and slightly crystalline microlites have their most intense exotherms at $460^{\circ}-570^{\circ} \mathrm{C}$, with weaker peaks near $600^{\circ}$ and $740^{\circ} \mathrm{C}$. Crystalline microlites $* 147$ and $* 201$ show weak exotherms at $545^{\circ} \mathrm{C}$ and $425^{\circ} \mathrm{C}$, respectively. In general, the results are consistent with previous work $[17,18]$. With the exception of samarskite $=250$, the pyrochlore group minerals can be distinguished from metamict $\mathrm{ABO}_{4}$ and $\mathrm{AB}_{2} \mathrm{O}_{6}$ oxides using DTA.

Endotherms were consistently detected at $140^{\circ}-190^{\circ} \mathrm{C}$ and $470^{\circ}-510^{\circ} \mathrm{C}$, corresponding to intervals of maximum weight loss recorded by TGA. Weight loss measurements indicate that $\mathrm{H}_{2} \mathrm{O}$ content varies dramatically, ranging from 0.1 to 11.3 weight percent. The metamict and altered samples tend to have the highest $\mathrm{H}_{2} \mathrm{O}$ contents. None of the pyrochlore group minerals showed a gain in weight which might be attributed to oxidation of Fe or U. The DTA traces of four samples are shown in Figure 1. The broad exotherm of microlite 153 (Fig. 1a) is unusual. Most of the pyrochlore group minerals give sharp exothermic peaks on heating (Fig. $1 \mathrm{~b}, \mathrm{C}, \mathrm{d}$ ). Multiple peaks are typical of the metamict and slightly crystalline microlites $* 168$ (Fig. ID) and $* 080$ from Amella, Virginia.

Exothermic peak areas were estimated for the full data set (Table 2) and converted to units of $\mathrm{J} / \mathrm{g}$ based on sample weights. For the pyrochlore group, recrystallization energy values, $E_{t}$, ranged from 4 to $200 \mathrm{~J} / g$. Crystalline microlites released 4 to $13 \mathrm{~J} / \mathrm{g}$. The moderately crystalline pyrochlore 230 had an energy release of $34 \mathrm{~J} / \mathrm{g}$. Metamict samples released from 20 to $200 \mathrm{~J} / \mathrm{g}$ of energy. Values ranging from 20 to $60 \mathrm{~J} / \mathrm{g}$ are suspect. For example betafite $* 155$ and pyrochlore $* 186$ are the most 
severely altered samples examined. Heating products of $* 155$ are pyrochlore, rutile, $\mathrm{UNb}_{3} \mathrm{O}_{8}$, and $\mathrm{UNb}_{3} \mathrm{O}_{10}$. Sample * 186 recrystallized to a mixture of pyrochlore and $\mathrm{Nb}-\mathrm{Ta}-\mathrm{Fe}-$ rutile. Samples $* 171$ and *251 may actually be samarskite (an $\mathrm{AB}_{2} \mathrm{O}_{6}$-oxide). Both recrystallize to pyrochlore + fergusonite + $\mathrm{FeNbO}_{4}$ and have DTA patterns similar to samarskite (*250). All three have stored energies near $40 \mathrm{~J} / \mathrm{g}$. Taking these exceptions into account, stored energy values of metamict pyrochlore group minerals range from 120 to $200 \mathrm{~J} / \mathrm{g}$. Of the minerals included for comparison, only fergusonite (an $\mathrm{ABO}_{4}$ oxide) approaches this range at 130 $\mathrm{J} / \mathrm{g}$ (Table 2). However, this value could be as low as $70 \mathrm{~J} / \mathrm{g}$ depending on the interpolation of background beneath three overlapping exotherms.

Samples $153,-168$, and $* 204$ were studied in greater detail. Activation energies were calculated using the relationship,

$$
K_{t}=A e^{-E a / k B T}
$$

where $k_{l}$ is the temperature dependent rate constant and $k_{B}$ is Boltzmann's constant. A plot of $\ln \left(k_{t}\right)$ versus $1 / T$ yields $E_{a} / k_{B}$ as the slope and $A$ for the $y$-intercept. Plots of the data are shown in Figure 2. Results of the calculations made from these plots are given in Table 3 with more precise values of $E_{L}$. Activation energies, $E_{z}$, range from 0.29 to $1.0 \mathrm{eV}$ with betafite ${ }^{*} 204$ having the highest value. For the microlites, additional determinations were made over an interval of $250^{\circ} \mathrm{C}$ below the exothermic maximum temperature. Similar results were obtained for microlite *153, 
but lower values of $E_{\mathrm{a}}$ and $A$ were obtained for $* 168$.

\section{DISCUSSION}

The data in Table 2 suggest that there is a compositional control on the exothermic peak temperature of natural pyrochlores. Generally, the betafites recrystallize at higher temperatures $\left(650^{\circ}-700^{\circ} \mathrm{C}\right)$ than do the pyrochlores or microlites $\left(400^{\circ}-600^{\circ} \mathrm{C}\right)$. These differences appear to correlate with departures from ideal $A_{2} B_{2} X_{6} Y$ stoichiometry and with the degree of hydration. The betafites approximate $\mathrm{AB}_{2} \mathrm{O}_{6}$ stoichiometry (e.g. *204, Table 1) with 10-12 wt. percent total water. Pyroctiores and microlites tend to have less than 0.50 vacancies per formula unit at the A-site and $Y$-site (microlites $* 153$ and $* 168$, Table 1 ) and less than 4 wt. percent total water. Large amounts of $\mathrm{H}_{2} \mathrm{O}$, which in molecular form may help to stabilize the structure by filling large voids formed by vacancies, may act to delay the recrystallization of betafites to higher temperatures.

Release of energy decreases as a function of increased crystallinity, with the fully-metamict samples approaching $210 \mathrm{~J} / \mathrm{g}$. The lowest values (4-13 $\mathrm{J} / \mathrm{g}$ ) are found for crystalline microlites. The energy release probably corresponds to annealing of isolated defects and defect aggregates. For partially metamict samples, the double exothermic peaks may represent the annealing of crystalline areas which are rich in aggregated point defects, while the nigher temperature exotherm represents the recrystallization of heavily-damaged, amorphous regions.

This is consistent with the interpretation of the DTA and small-angle 
$x$-ray scattering data for partially metamict titanites $\left(\mathrm{CaTiSiO}_{5}\right)$ [24] and transmission electron microscopy on partially-metamict zirconolites [21].

Most of the metamict specimens release $125-210 \mathrm{~J} / \mathrm{g}$ with recrystallization. Lower values found for betafites *155 and *186 appear to be the result of severe alteration and breakdown into multiphase assemblages. These assemblages are reflected by the heating products of both samples (Table 4). Estimated $E_{t}$ values of metamict pyrochlores are greater than those of samarskite $(40-50 \mathrm{~J} / \mathrm{g})$ and other $\mathrm{AB}_{2} \mathrm{O}_{6}$ oxides $(50-70 \mathrm{~J} / \mathrm{g})$. In addition, the pyrochlore derivative structures of zirconolite and zirkelite give lower $E_{\mathrm{t}}$ values of $40-50 \mathrm{~J} / \mathrm{g}$ [19]. These differences are intriguing, considering the similar saturation dose levels of natural pyrochlores (1-4 $\times 10^{16}$ alphas/mg [16]) and zirconolites (0.6-2.0 $\times 10^{16}$ alphas $/ \mathrm{mg} ;=0.3-1.0 \times 10^{26}$ alphas $/ \mathrm{m}^{3}[20]$ ). Even the evolution of damage-microstructures, as observed by high resolution transmission electron microscopy, appear to be comparable $[16,21]$.

In a systematic study of synthetic cubic zirconolite (CaPuTi $\left.{ }_{2} \mathrm{O}_{7}\right)$, Foltyn et al. [22] found that the stored energy reaches a maximum near the saturation dose level defined by swelling $\left(0.4 \times 10^{16}\right.$ alphas $/ \mathrm{mg} ;=0.2 \times$ $10^{26}$ alphas $/ \mathrm{m}^{3}$ ). Beyond this value the fully-metamict state is reached at $10^{16}$ alphas/mg as determined by TEM, accompanied by a reduction in $E_{t}$ approaching 50 percent of the saturation value at a dose of $3 \times 10^{16}$ alphas $/ \mathrm{mg}\left(=1.5 \times 10^{26}\right.$ alphas $\left./ \mathrm{m}^{3}\right)$. The stored energy at this point is 50 $\mathrm{J} / \mathrm{g}$, close to that of the natural zirconolites. The decrease in stored energy was attributed to "redamaging processes" leading to reduced disorder within the aperiodic structure or to reduced internal strain. 
Krivokoneva and Sidorenko [18] examined the $x$-ray diffraction line broadening of natural pyrochlores and found a significant strain component which increased with increasing alpha-recoil damage. Similarly, lattice expansion in synthetic, ${ }^{244} \mathrm{Cm}$-doped zirconolite $\left(\mathrm{CazrTi}_{2} \mathrm{O}_{7}\right)$ produces strain components which increase as a function of alpha-recoil dose [23]. Unlike the synthetic zirconolites [22], the natural pyrochlores do not show much variation in stored energy near the saturation dose and beyond. For instance, microlite $* 168$ has experienced a dose of $0.2 \times 10^{16}$ alphas $/ \mathrm{mg}$ and microlite $=153$ a dose of $4 \times 10^{16}$ alphas $/ \mathrm{mg}$, similar to values given above for synthetic zirconolites. However, the $E_{\mathrm{t}}$ value of $* 153$ is greater than that of $* 168$ (Tables 2,3 ). Either the pyrochlore group minerals do not experience strain relaxation or the amount of strain involved is much less than in the synthetic zirconolites.

Detailed measurements in Table 3 suggest that the activation energies, $E_{\mathbf{a}}$ correlate with peak temperatures of exotherms. Values of $E_{t}$ appear to correlate inversely with $\mathrm{E}_{\mathrm{a}}$ for the three pyrochlores. This may be the result of composition differences (Table 1), particularly for samples $* 153$ and $* 204$ which have nearly the same dose of $\sim 4 \times 10^{16}$ alphas $/ \mathrm{mg}$. For the pyrochlore group minerals, $E_{\mathbf{a}}$ ranges from 0.29 to $0.97 \mathrm{eV}$. These values exceed that of ${ }^{244} \mathrm{Cm}$-doped glass $(0.25 \mathrm{eV}$ ) but fall below the value found for synthetic $\mathrm{CaPuTi}_{2} \mathrm{O}_{7}(1.22 \mathrm{eV})$. In addition, the metamict pyrochlores release higher levels of energy during recrystallization relative to most other alpha-damaged natural or synthetic oxides and glasses. 


\section{CONCLUSIONS}

The recrystallization energy values, $E_{t}$, for metamict members of the pyrochlore group range from $125-210 \mathrm{~J} / \mathrm{g}$. Samples with lower values, in the range of 40 to $125 \mathrm{~J} / \mathrm{g}$, are almost certainly due to the fact that they have been altered. Other metamict, complex oxides with stoichiometries of $\mathrm{ABO}_{4}$ (e.g fergusonite) or $\mathrm{AB}_{2} \mathrm{O}_{6}$ (e.g. samarskite) have lower values of recrystallization energy, $40-85 \mathrm{~J} / \mathrm{g}$, and thus are easily distinguished from pyrochlore group minerals. The temperature of the exotherm of recrystallization varies between $400^{\circ}$ and $700^{\circ} \mathrm{C}$, the exact temperature determined by the sample composition (i.e. $400^{\circ}-600^{\circ} \mathrm{C}$ for pyrochlores and microlites; $650^{\circ}-700^{\circ} \mathrm{C}$ for betafites. The betafites characteristically have a greater number of A-site cation deficiencies and a higher content of $\mathrm{H}_{2} \mathrm{O}$, both of which may be related to the higher temperature of the recrystallization exotherm. The $E_{\mathrm{t}}$ values for the pyrochlore group minerals are consistently higher than those measured in synthetic, Pu-doped zirconolite $\left(50 \mathrm{~J} / \mathrm{g}\right.$ at doses of $3 \times 10^{16}$ alphas $/ \mathrm{mg}=$ $1.5 \times 10^{26}$ alphas $\left./ \mathrm{m}^{3}\right)$ and natural zirconolite $(40-50 \mathrm{~J} / \mathrm{g}$ at doses of $2 \times$ $10^{16}$ alphas $/ \mathrm{mg}=1.0 \times 10^{26}$ alphas $\left./ \mathrm{m}^{3}\right)$. The data do not suggest a decrease in energy for pyrochlore group minerals at doses beyond the saturation value as a result of either (i) reordering at the atomic level of already damaged areas or (ii) a reduction of internal strain by the same redamaging process [22].

Activation energies of recrystallization, $E_{a}$, range between values of 0.29 to $0.97 \mathrm{eV}$. Higher activation energies are measured for the 
exotherms at higher temperatures. The activation energies are intermediate between those measured for a ${ }^{244} \mathrm{Cm}$-doped glass $(0.25 \mathrm{eV})$ and that for synthetic CaPuTi ${ }_{2} \mathrm{O}_{7}(1.22 \mathrm{eV})$. This range of activation energies suggests real differences in the annealing history of alpha-recoil damage in complex-oxides of different stoichiometries (e.g. $\mathrm{AB}_{2} \mathrm{O}_{6}$ vs. $\mathrm{A}_{2} \mathrm{~B}_{2} \mathrm{O}_{7}$ ) and structures (e.g. pyrochlore vs. zirconolite) during the thermal history of a nuclear waste repository.

\section{ACKNOWLEDGMENTS}

This work was supported by the U.S. Department of Energy, Orfice of Basic Energy Sciences under grant =DE-FG04-84ER45099 (R. C. Ewing). The paper has benefitted from a critical review by B. C. Chakoumakos.

\section{REFERENCES}

[1] P. E. D. Morgan, A. B. Harker, J. F. Flintoff, T. M. Shaw and D. R. Clarke, Advances in Ceramics 8, eds. G. G. Wicks and W. A. Ross (American Ceramic Society, Columbus, 1984) p. 234.

[2] A. B. Harker and J. F. Flintoff, The Scientific Basis for Nuclear Waste Management VII, ed. G. McVay (Elsevier, New York, 1984) p. 513.

[3] P. E. D. Morgan, T. M. Shaw and E. A. Pugar, Advances in Ceramics 8, 
eds. G. G. Wicks and W. A. Ross (American Ceramic Society, Columbus, 1984) p. 209.

[4] A. E. Ringwood, Mineral. Mag. 49 (1985) 159.

[5] J. L. Hutchison, J. C. Barry, R. L. Segall and T. J. White Proc. EMAG 1983 Conference, Guildford Institute of Physics Conference Series, No. $68(1984) 403$.

[6] J. A. Cooper, D. R. Cousens, R. A. Lewis, S. Myhra, R. L. Segall, R. St. C. Smart, P. S. Turner and T. J. White, J. Am. Ceram. Soc. 68 (1985) 64.

[7] T. J. White, R. L. Segall, J. L. Hutchison and J. C. Barry, Proc. R. Soc. Lond. A392 (1984) 343.

[8] F. W. Clinard, Jr., D. L. Rohr and R. B. Roof, Nucl. Instr. Meth. Phys. Res. B1 (1984) 581 .

[9] F. W. Clinard, Jr., D. E. Peterson and D. L. Rohr, J. Nucl. Mat. 126 (1984) 245.

[10] J. W. Wald and P. Offerman, The Scientific Basis for Nuclear Waste Management V, vol. 11, ed. W. Lutze (Elsevier, New York, 1982) p. 369.

[11] J. W. Wald and W. J. Weber, Advances in Ceramics 8, eds. G. G. Wicks and W. A. Ross (American Ceramic Society, Columbus, 1984) p. 71. 
[12] D. D. Hogarth, Amer. Mineral. 62 (1977) 403.

[13] G. R. Lumpkin and R. C. Ewing, Scientific Basis for Nuclear Waste Management VIII, vol. 44, eds. C. M. Jantzen, J. A. Stone and R. C. Ewing (Materials Research Society, Pittsburgh, 1985) p. 647.

[14] J. W. Colby, Advances in X-ray Analysis 11 (1968) 287.

[15] D. E. Appleman and H. T. Evans, Jr., Natl. Tech. Inf. Serv. Document PB-216 (1973) 188 pages.

[16] G. R. Lumpkin, B. C. Chakoumakos and R. C. Ewing, Amer. Mineral. 71 (1986) in press.

[17] D. D. Hogarth, Càn. Mineral. 6 (1961) 610.

[18] G. K. Krivokoneva and G. A. Sidorenko, Geochem. Int. (1971) 113.

[19] G. R. Lumpkin and others, Radiation Effects in Natural Zirconolites, J. of Mat. Res., in preparation.

[20] R. C. Ewing, R. F. Haaker, T. J. Headley and P. F. Hlava, The Scientific Basis for Nuclear Waste Management, vol. 6, ed. S. V. Topp (Elsevier, New York, 1982) p. 249.

[21] R. C. Ewing and T. J. Headley, J. Nucl. Mat. 119 (1983) 102. 
October 1. 1985

[22] E. M. Foltyn, F. W. Clinard, Jr., J. Rankin and D. E. Peterson, J. Nucl. Mat., in press.

[23] B. C. Chakoumakos and R. C. Ewing, Geol. Soc. of Am. Abst. (1985).

[24] E. R. Vance and J. B. Metson, Phys. Chem. Minerals. 12 (1985) 255 


\section{FIGURE CAPTIONS}

FIGURE 1. DTA traces of pyrochlore group minerals showing commonly observed exothermic and endothermic effects (refer to Table 2).

FIGURE 2. Temperature dependence of the rate constant $k_{t}$ determined for two microlites and one betafite (refer to Table 3). 
Table 1. Electron microprobe analyses and structural formulas of three natural pyrochlore group minerals.

\begin{tabular}{|c|c|c|c|c|c|c|c|}
\hline & 204 & 153 & 168 & & 204 & 153 & 168 \\
\hline $\mathrm{WO}_{3}$ & -- & 0.06 & 0.47 & $W$ & -- & 0.00 & 0.01 \\
\hline $\mathrm{Ta}_{2} \mathrm{O}_{5}$ & 1.74 & 70.2 & 63.9 & $\mathrm{Ta}$ & 0.03 & 1.77 & 1.53 \\
\hline $\mathrm{Nb}_{2} \mathrm{O}_{5}$ & 34.1 & 4.77 & 8.11 & $\mathrm{Nb}$ & 1.07 & 0.20 & 0.32 \\
\hline $\mathrm{TiO}_{2}$ & 17.2 & 0.40 & 0.53 & $\mathrm{Ti}$ & 0.90 & 0.03 & 0.04 \\
\hline $\mathrm{ZrO}_{2}$ & 0.03 & -- & - & $\mathrm{Sn}$ & - & 0.00 & 0.10 \\
\hline $\mathrm{SnO}_{2}$ & -- & 0.00 & 2.77 & & & & \\
\hline $\mathrm{ThO}_{2}$ & 0.32 & 0.00 & 0.03 & $\Sigma \mathrm{B}$ & 2.00 & 2.00 & 2.00 \\
\hline $\mathrm{UO}_{2}$ & 24.5 & 8.56 & 2.62 & & & & \\
\hline $\mathrm{Y}_{2} \mathrm{O}_{3}$ & 0.27 & 0.00 & 0.13 & U & 0.38 & 0.18 & 0.05 \\
\hline $\mathrm{RE}_{2} \mathrm{O}_{3}$ & 0.86 & 0.13 & 0.24 & $\mathrm{REE}$ & 0.03 & 0.00 & 0.01 \\
\hline $\mathrm{Sb}_{2} \mathrm{O}_{3}$ & -- & 0.05 & 0.13 & $\operatorname{Mn}$ & 0.02 & 0.01 & 0.00 \\
\hline $\mathrm{Bi}_{2} \mathrm{O}_{3}$ & $-\infty$ & 0.17 & 0.11 & $\mathrm{Fe}$ & 0.18 & 0.01 & 0.01 \\
\hline Mno & 0.42 & 0.09 & 0.04 & $\mathrm{Ca}$ & 0.56 & 0.86 & 1.25 \\
\hline Feo & 3.04 & 0.06 & 0.07 & $\mathrm{~Pb}$ & 0.01 & 0.05 & 0.00 \\
\hline $\mathrm{CaO}$ & 7.49 & 8.62 & 13.2 & $\mathrm{Na}$ & 0.01 & 0.60 & 0.42 \\
\hline Sro & 0.01 & -- & $-\infty$ & $\square A$ & 0.81 & 0.29 & 0.26 \\
\hline $\mathrm{BaO}$ & 0.08 & 0.00 & 0.02 & & & & \\
\hline $\mathrm{Pbo}$ & 0.51 & 1.85 & 0.03 & 0 & 6.11 & 6.39 & 6.25 \\
\hline $\mathrm{Na}_{2} \mathrm{O}$ & 0.05 & 3.32 & 2.46 & $\mathbf{F}$ & 0.05 & 0.37 & 0.58 \\
\hline $\mathrm{Cs}_{2} \mathrm{O}$ & $-\infty$ & 0.02 & 0.00 & $\square Y$ & 0.84 & 0.24 & 0.17 \\
\hline $\mathrm{H}_{2} \mathrm{O}$ & 8.5 & 1.2 & 3.8 & . & & & \\
\hline F & 0.24 & 1.25 & 2.09 & $\mathrm{H}_{2} \mathrm{O}$ & 1.97 & 0.37 & 1.12 \\
\hline SUM & 99.55 & 100.75 & 100.75 & & & & \\
\hline $0=F$ & -0.10 & -0.53 & -0.88 & dose* & 3.7 & 4.0 & 0.2 \\
\hline TOTAL & 99.45 & 100.22 & 99.87 & dpa** & 41 & 45 & 2.6 \\
\hline
\end{tabular}

* n $\times 10^{16} \alpha / \mathrm{mg}$

** displacements per attom 
Table 2. DTA/TGA data for pyrochlore group, $\mathrm{ABO}_{4}$, and $\mathrm{AB}_{2} \mathrm{O}_{6}$ type oxide minerals.

\begin{tabular}{|c|c|c|c|c|c|c|c|c|}
\hline \multirow{2}{*}{$\begin{array}{l}\text { Sample No. } \\
\text { BETAFITE SUBGROU }\end{array}$} & \multirow[t]{2}{*}{ Museum No. } & \multicolumn{3}{|c|}{$\begin{array}{c}\text { Exotherms } \\
\left({ }^{\circ} \mathrm{C}\right)\end{array}$} & \multicolumn{2}{|c|}{$\begin{array}{l}\text { Endotherms } \\
\left({ }^{\circ} \mathrm{C}\right)\end{array}$} & \multirow[t]{2}{*}{$\begin{array}{c}\text { Wt. Loss } \\
(\%)\end{array}$} & \multirow[t]{2}{*}{$E_{T}(J / g)$} \\
\hline & & & & & & & & \\
\hline 155 Madagascar & so 52559 & & 650 & & 180 & & $10.1 \%$ & 13 \\
\hline 171 Madagascar & AMNH 21590 & 425 & 700 & & 160 & 475 & 6.6 & 50 \\
\hline 178 Mexico & AMNH 28426 & & 675 & & 185 & & 9.8 & 184 \\
\hline 186 Finland & AMNH 17758 & & 700 & & 175 & & 11.3 & 63 \\
\hline 204 Canada & HO 124374 & & 660 & & 165 & 480 & 8.5 & 126 \\
\hline \multicolumn{9}{|c|}{ PYROCHLORE SUBGROUP } \\
\hline 214 Canada & HU 1024503 & 410 & 620 & & 140 & & 3.8 & 143 \\
\hline 230 USSR & W.W. Pinch & 430 & 570 & & & $490(?)$ & 1.0 & 34 \\
\hline 251 New Mexico & UNM & 425 & 700 & & 165 & 490 & 7.2 & 42 \\
\hline \multicolumn{9}{|c|}{ MICROLITE SUBGROUP } \\
\hline 080 Virginia & USNM 96739 & 570 & 740 & & 150 & & 1.0 & 201 \\
\hline 147 New Mexico & UNM & 545, & weak & & & & 0.1 & 4 \\
\hline 153 New Mexico & UNM & 465 & 600 & & 160 & & 1.2 & 214 \\
\hline 168 Virginia & AMNH 067251 & 545 & 615 & 740 & 170 & & 3.8 & 147 \\
\hline 201 Maine & HU 90883 & 425, & weak & & & & 1.2 & 13 \\
\hline \multicolumn{9}{|l|}{$\mathrm{ABO}_{4}$ OXIDES } \\
\hline 124 Fergusonite & UNM & 485 & 580 & 670 & 160 & & & $130^{*}$ \\
\hline \multicolumn{9}{|l|}{$\mathrm{AB}_{2} \mathrm{O}_{6}$ OXIDES } \\
\hline 227 Brannerite & UNM & 510 & 655 & 800 & & & & 71 \\
\hline 250 Samarskite & J.W. Adams & 465 & 645 & & 155 & 390 & & 41 \\
\hline R3 Aeschynite & C.O. Button & 305 & 495 & 725 & 450 & 525 & & 50 \\
\hline R5 Polycrase & C.0. Hutton & 335 & 530 & 770 & 120 & 395 . & & 59 \\
\hline R18 Euxenite & C.0. Button & 360 & 740 & 900 & & 400 & & 63 \\
\hline
\end{tabular}

* could be as 10 as $70 \mathrm{~J} / \mathrm{g}$, see text. 
Table 3. DTA data for pyrochlore group minerals compared to synthetic zirconolite and glasses.

\begin{tabular}{|c|c|c|c|c|c|c|}
\hline Sample No. & Temp. Range & Peak & Interval & $E_{a}(e V)$ & $A\left(s^{-1}\right)$ & $E_{T}(J / g)$ \\
\hline 153 Microlite & $\begin{array}{l}200-780^{\circ} \mathrm{C} \\
200-455\end{array}$ & $465^{\circ} \mathrm{C}$ & $\begin{array}{l}80^{\circ} \mathrm{C} \\
17.5\end{array}$ & $\begin{array}{l}0.29 \\
0.34\end{array}$ & $\begin{array}{l}0.14 \\
0.34\end{array}$ & 259 \\
\hline 168 Microlite & $\begin{array}{l}300-880 \\
300-535\end{array}$ & 545 & $\begin{array}{l}60 \\
15\end{array}$ & $\begin{array}{l}0.53 \\
0.15\end{array}$ & $\begin{array}{l}0.87 \\
0.0014\end{array}$ & $\begin{array}{l}181 \\
+\end{array}$ \\
\hline 204 Betafite & $440-800$ & 660 & 40 & 0.97 & 570 & 133 \\
\hline $\mathrm{CaPuTI}_{2} \mathrm{O}_{7}$ & $485-715$ & & & 1.22 & 60,000 & 28 \\
\hline $\begin{array}{l}{ }^{244} \text { Cm-doped } \\
\text { glasses [13] }\end{array}$ & & & & 0.25 & & 117 \\
\hline
\end{tabular}


Table 4. X-ray diffraction data (nm) on annealed samples.

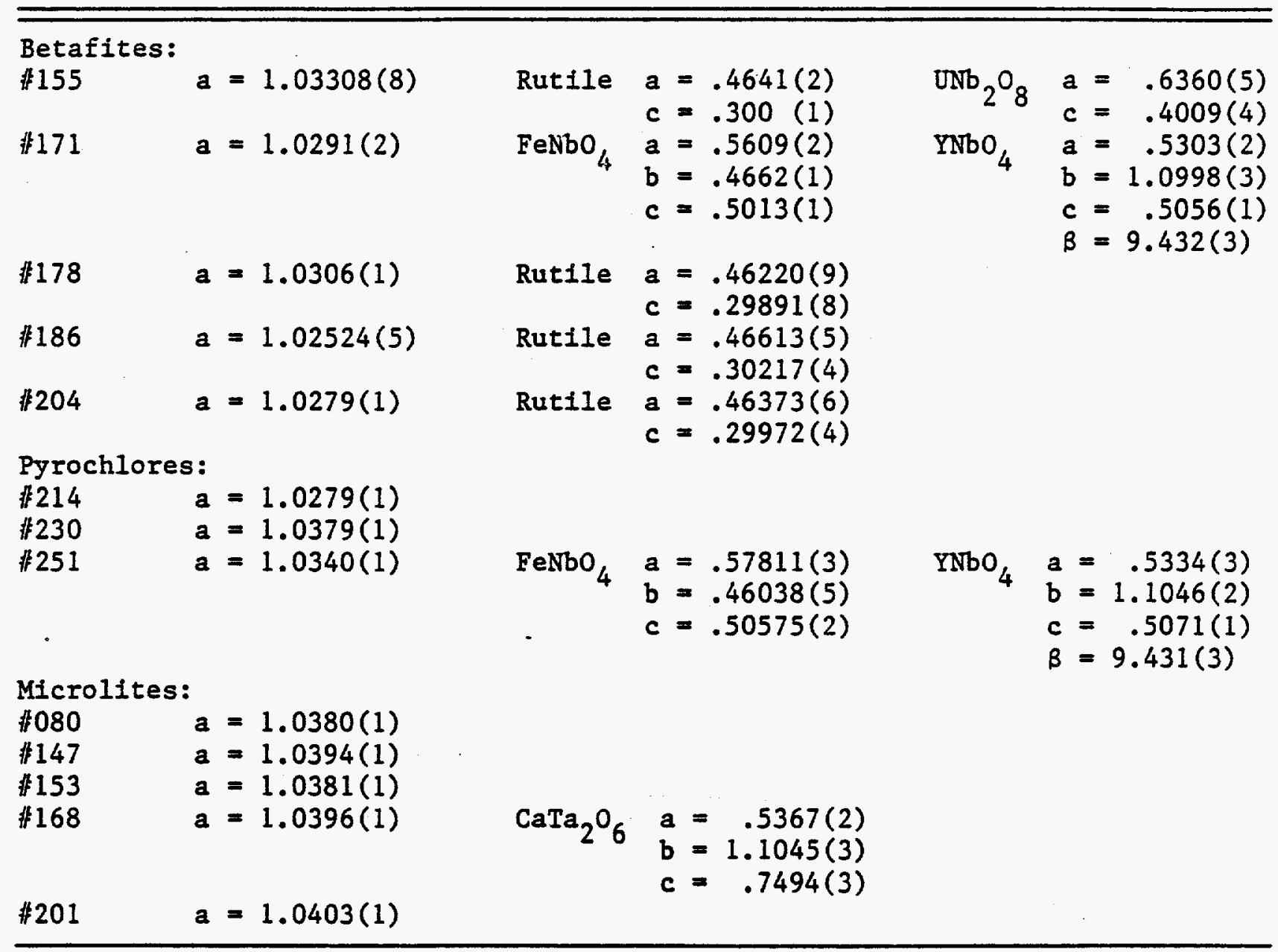

